\title{
Pengaruh Partisipasi Anggaran, Asimetri Informasi, Ketidakpastian Lingkungan, Budaya Organisasi dan Komitmen Organisasi Pada Senjangan Anggaran
}

\author{
Anak Agung Gde Wimba Wardhana ${ }^{1}$ \\ Gayatri $^{2}$
}

\author{
${ }^{1}$ Fakultas Ekonomi dan Bisnis Universitas Udayana (Unud), Bali, Indonesia \\ email: wimba_wardhana@yahoo.co.id/ Telp : 081236880890 \\ ${ }^{2}$ Fakultas Ekonomi dan Bisnis Universitas Udayana (Unud), Bali, Indonesia
}

\begin{abstract}
ABSTRAK
Senjangan anggaran merupakan proses penganggaran yang ditemukan adanya distorsi secara sengaja dengan menurunkan pendapatan yang dianggarkan dan meningkatkan biaya yang dianggarkan. Penelitian ini bertujuan untuk mengetahui pengaruh partisipasi penganggaran, asimetri informasi, ketidakpastian lingkungan, budaya organisasi dan komitmen organisasi pada senjangan anggaran di RSU Negara Kabupaten Jembrana. Penelitian ini dilakukan pada pegawai yang berwenang dalam penyusunan anggaran di RSU Negara sebanyak 40 orang. Hasil pengujian hipotesis menunjukkan bahwa variabel partisipasi anggaran berpengaruh positif terhadap senjangan anggaran, asimetri informasi berpengaruh positif terhadap senjangan anggaran, ketidakpastian lingkungan berpengaruh positif terhadap senjangan anggaran, budaya organisasi berpengaruh negatif terhadap senjangan anggaran, dan komitmen organisasi berpengaruh negatif terhadap senjangan anggaran.

Kata Kunci: partisipasi anggaran, asimetri informasi, ketidakpastian lingkungan, budaya organisasi, komitmen organisasi, senjangan anggaran
\end{abstract}

\begin{abstract}
Budgetary slack is a budgeting process that found intentional distortion by lowering budgeted revenues and increasing budgeted costs. This study aims to determine the effect of budgetary participation, information asymmetry, environmental uncertainty, organizational culture and organizational commitment on budget slack at State General Hospital Jembrana District. This research was conducted on the authorized personnel in budget preparation at RSU Negara as many as 40 people. The result of hypothesis testing shows that budget participation variable has positive effect on budget slack, information asymmetry has positive effect on budget slack, environmental uncertainty has positive effect on budget slack, organizational culture has negative effect on budget slack, and organizational commitment has negative effect on budget slack.

Keywords: budgetary participation, information asymmetry, environmental uncertainty, organizational culture, organizational commitment, budgetary slack
\end{abstract}


Anak Agung Gde Wimba Wardhana dan Gayatri. Pengaruh...

\section{PENDAHULUAN}

Rumah Sakit merupakan suatu institusi pelayanan kesehatan dengan menyelenggarakan suatu pelayanan kesehatan perorangan secara menyeluruh dengan fasilitas pelayanan rawat inap, rawat jalan, dan gawat darurat. Rumah Sakit Umum (RSU) Negara adalah salah satu Organisasi Perangkat Daerah (OPD) dilingkungan Pemerintah Kabupaten Jembrana yang merupakan unsur penunjang penyelenggaraan pemerintah daerah dibidang Pelayanan Kesehatan. RSU Negara juga merupakan salah satu OPD di lingkungan Pemerintah Kabupaten Jembrana yang menerapkan Pola Pengelolaan Keuangan Badan Layanan Umum Daerah (BLUD). Rumah sakit yang menggunakan BLUD memperoleh dana dari Anggaran Pendapatan dan Belanja Negara (APBN) untuk biaya operasional dan belanja modal. Biaya operasional biasanya digunakan untuk biaya gaji pegawai dan biaya pemeliharaan aktiva tetap.

Salah satu cara agar biaya operasional berjalan secara efektif dan efisien adalah dengan menggunakan anggaran sebagai alat perencanaan dan pengendalian perusahaan (Schief dan Lewin, 1970). Anggaran dapat membantu manajemen untuk mengelola perusahaan dengan baik sehingga dapat mencapai tujuan jangka pendek dan jangka panjang. Penggunaan anggaran sebagai alat bantu manajemen dalam mengelola perusahaan dapat membantu manajemen untuk menghindari kesalahan melakukan alokasi sumber daya perusahaan, karena dalam penyusunan anggaran tersebut berbagai aspek diperhatikan baik dari aspek internal maupun eksternal perusahaan dijadikan bahan pertimbangan dalam penyusunan anggaran (Widyaningtyas, 2017:2). 
Agency theory menyatakan bahwa bawahan akan membuat target yang lebih mudah untuk dicapai dengan cara membuat target anggaran yang lebih rendah pada sisi pendapatan, dan membuat ajuan biaya yang lebih tinggi pada sisi biaya. Hal tersebut akan membuat kinerja dari manajemen akan terlihat baik karena dapat mencapai target. Perbedaaan antara anggaran yang dilaporkan dengan anggaran yang sesuai dengan estimasi terbaik bagi perusahaan ini disebut senjangan anggaran. Menurut Siegel dan Marconi (2009) menyebutkan senjangan anggaran merupakan perbedaan jumlah anggaran yang diajukan oleh bawahan dengan jumlah estimasi yang terbaik dari organisasi.

Teori pendukung dalam penelitian ini yaitu teori penetapan tujuan atau goal setting theory yang dikemukakan oleh Locke (1968) menunjukkan adanya keterkaitan antara tujuan dan kinerja seseorang terhadap tugas. Mirayanti (2012) menemukan bahwa goal-setting berpengaruh pada kinerja pegawai dalam organisasi publik. Salah satu bentuk nyata dari penerapan goal-setting ini adalah anggaran. Sebuah anggaran tidak hanya mengandung rencana dan jumlah nominal yang dibutuhkan untuk melakukan kegiatan, tetapi juga mengandung sasaran yang spesifik yang ingin dicapai organisasi.

Banyak penelitian sebelumnya meneliti senjangan anggaran di dinas, hotel berbintang, PT (Perseroan Terbatas) dan lainnya. Tetapi penelitian ini akan meneliti tentang organisasi pemerintahan dibidang pelayanan kesehatan yaitu Rumah Sakit Umum Daerah Negara Kabupaten Jembrana. Alasan rumah sakit dipilih karena (1) proses penyusunan anggaran pada rumah sakit mempunyai tingkat kompleksitas yang lebih rendah dibandingkan perusahaan manufaktur, (2) 
rumah sakit bertujuan meminimalkan biaya dan memaksimalkan pelayanan, (3) untuk meningkatkan pelayanan, maka diperlukan perencanaan dan pengawasan biaya dengan tingkat kompleksitas yang berbeda.

Dugaan terjadinya senjangan anggaran dapat dilihat dari laporan anggaran dan belanja dirumah sakit umum Negara yang menunjukan pendapatan tahun 2012 sampai 2016 dibuat lebih rendah sedangkan realisasinya menunjukan hasil yang tinggi, diartikan pihak rumah sakit menargetkan anggaran yang kecil agar mudah untuk dicapai serta penilaian kerja yang baik karena dapat mencapai target anggaran. Sedangkan anggaran belanja pada tahun 2012 sampai 2016 menunjukan anggaran belanja yang tinggi sedangkan realisasinya yang dibuat rendah, yang diartikan dengan sengaja pihak rumah sakit agar terlihat efisien menggunakan anggaran, sehingga terlihat baik dalam penggunaan anggaran belanja.

Senjangan anggaran dapat terjadi ketika orang-orang yang terlibat dalam menciptakan anggaran sengaja melebih-lebihkan jumlah biaya selama periode anggaran. Selain itu adanya senjangan anggaran berarti, tidak tercapainya tujuan kinerja yang baik dalam pemerintahan, sehingga pemerintah akan tampak gagal dalam menjalankan prinsip anggaran dalam anggaran sektor publik. Senjangan anggaran pada pemerintah daerah terjadi karena adanya perilaku oportunistik dalam instansi pemerintah. Anggaran yang disusun dengan partisipasi anggaran yang salah akan menyebabkan kerugian bagi para pihak stakeholder dan pihak shareholder.

Perilaku oportunistik adalah perilaku atau tindakan seseorang yang menyimpang dari peraturan-peraturan yang ada untuk memenuhi segala 
keinginannya (Sularso dkk., 2014). Perilaku oportunistik tersebut meliputi mengusulkan kegiatan yang sesungguhnya tidak menjadi prioritas, mengusulkan kegiatan yang memiliki lucrative opportunities (peluang untuk mendapatkan keuntungan pribadi) yang besar, mengalokasikan komponen belanja yang tidak penting dalam suatu kegiatan, mengusulkan jumlah belanja yang terlalu besar untuk komponen belanja dan anggaran setiap kegiatan, dan memperbesar anggaran untuk kegiatan yang sulit diukur hasilnya dalam proses penyusunan anggaran. Perilaku oportunistik nantinya akan mengarah pada tindakan seperti menyembunyikan informasi dan menyalahgunakan kewenangan yang dimiliki.

Anggaran partisipatif merupakan metode yang paling baik dalam penyusunan anggaran (Yanti, 2016). Metode ini mengikutsertakan pegawai yang menyusunan anggaran dirumah sakit dengan menentukan, bagaimana anggaran akan disusun sesuai dengan sasaran anggaran pada bagian atau divisi masingmasing. Pegawai yang menyusun anggaran setiap bagian atau divisi dalam rumah sakit dilibatkan dalam proses penyusunan anggaran karena mereka mempunyai kecukupan informasi untuk memprediksi masa depan secara tepat, sehingga keterlibatan mereka mengurangi kecenderungan individu yang terlibat didalam proses penyusunan anggaran untuk melakukan kesenjangan anggaran (Winarni, 2014:2). Namun partisipasi dalam penganggaran juga memberikan kesempatan kepada bawahan untuk menentukan rencana anggarannya. Kesempatan ini dapat digunakan secara negatif sehingga dapat menimbulkan senjangan dalam anggaran. 
Berdasarkan teori agensi yang menyatakan tentang keterlibatan antara pihak direktur rumah sakit dengan pihak pengelola penyusunan anggaran dirumah sakit dalam proses penyusunan anggaran. Partisipasi anggaran adalah suatu proses dalam organisasi yang melibatkan individu-individu, yakni pihak penyusun anggaran disetiap bidangnya masing-masing dalam penyusunan anggaran untuk menentukan tujuan anggaran dan mempunyai target anggaran. Partisipasi dari pihak penyusunan anggaran disetiap bidang sangatlah penting karena pihak pengelolaan anggaran disetiap bidang dirumah sakit yang lebih mengetahui kondisi langsung dari daerah tanggung jawabnya. Partisipasi dalam proses penyusunan anggaran, menyebabkan kemungkinan timbulnya senjnagan anggaran akan lebih besar karena individu tersebut memiliki kesempatan untuk melakukan manipulasi terhadap anggaran.

Pernyataan tersebut sejalan dengan hasil penelitian Armaeni (2012), Marfuah (2014), Maharani (2015), dan Yanti (2015), yang menyatakan bahwa partisipasi anggaran berpengaruh positif terhadap senjangan anggaran dan bermakna bahwa semakin tinggi tingkat partisipasi anggaran maka semakin tinggi pula tingkat senjangan anggaran yang ditimbulkan. Berdasarkan uraian tersebut dirumuskan hipotesis seperti berikut:

$\mathrm{H}_{1} \quad$ : Partisipasi anggaran berpengaruh positif pada senjangan anggaran.

Senjangan yang terjadi pada proses penyusunan anggaran juga dapat disebabkan oleh adanya asimetri informasi antara pihak penyusun anggaran dirumah sakit dengan direktur rumah sakit. Asimetri informasi merupakan perbedaan informasi yang dimiliki oleh direktur rumah sakit dengan pegawai yang 
menyusun anggaran disetiap bidangnya masing-masing, karena adanya perbedaan sumber dan akses atas informasi tersebut. Partisipasi yang dilakukan oleh pegawai penyusun anggaran dirumah sakit dalam menyusun anggaran dapat memberikan kesempatan untuk memasukkan informasi lokal yang dimilikinya. Dengan demikian, pegawai penyusun anggaran tersebut dapat mengkomunikasikan atau mengungkapkan beberapa informasi yang mungkin dapat dimasukkan dalam anggaran. De Faria dan Silva (2013) menyatakan bahwa asimetri informasi digunakan oleh bawahan untuk menyembunyikan informasi mengenai kinerjanya, yang mengakibatkan kurangnya motivasi untuk meningkatkan hasil karena ketidakmampuannya ditutupi oleh asimetri informasi dengan memberikan informasi yang bias, sehingga dapat dikatakan asimetri informasi merupakan pemicu senjangan anggaran.

Berdasarkan teori agensi yang menyatakan direktur rumah sakit dan pegawai yang menyusun anggaran disetiap bidang memiliki kualitas dan jumlah informasi yang tidak sama sehingga terdapat informasi tersembunyi yang dapat digunakan untuk kepentingan dirinya sendiri. Asimetri informasi mengacu pada ketidakpastian yang disebabkan oleh pegawai pengelolaan anggaran dirumah sakit yang memiliki informasi lebih tentang bidangnya dibandingkan direktur rumah sakit .

Asimetri informasi sering kali dimanfaatkan oleh bawahan untuk memenuhi kebutuhan pribadinya, dimana bawahan cenderung memberikan informasi bias kepada atasannya. Penelitian yang dilakukan oleh Armaeni (2012), Rukmana (2013), Arthaswadaya (2015), Putra (2015), Tresnayani (2016) menunjukkan 
bahwa adanya pengaruh positif dari asimetri informasi pada senjangan anggaran. Berdasarkan uraian tersebut dirumuskan hipotesis seperti berikut:

$\mathrm{H}_{2}$ : Asimetri informasi berpengaruh positif pada senjangan anggaran.

Ketidakpastian lingkungan adalah variabel lain yang dipertimbangkan dalam penelitian ini. Ketidakpastian lingkungan yang tinggi didefinisikan sebagai rasa ketidakmampuan individu untuk memprediksi sesuatu yang terjadi di lingkungannya secara akurat (Milliken, 1987). Kemampuan memprediksi keadaan di masa datang pada kondisi ketidakpastian lingkungan yang rendah dapat terjadi pada individu yang terlibat dalam penyusunan anggaran. Pada kondisi ini pegawai yang menyusun anggaran dapat memberikan informasi yang real yang dimiliki kepada direktur rumah sakit dalam penyusunan anggaran sehingga anggaran dapat lebih akurat namun dapat terjadi juga sebaliknya.

Menurut teori goal-setting, apabila individu menghadapi kondisi ligkungan yang tidak pasti, akan membuat realisasi anggaran (anggaran aktual) tidak sesuai dengan anggaran yang telah ditetapkan sebelumnya, sehingga akan memperkecil pencapaian ketepatan anggaran pendapatan dan belanja daerah (Locke, 1968). Ketidakpastian lingkungan merupakan salah satu faktor yang sering menyebabkan organisasi melakukan penyesuaian terhadap kondisi organisasi dengan lingkungan.

Disaat kondisi ketidakpastian lingkungan yang tinggi, pegawai yang menyusun anggaran sulit memprediksi masa yang akan datang karena ketidakadaan informasi yang akurat sehingga bawahan sulit menciptakan senjangan anggaran. Penelitian yang dilakukan oleh Kartika (2010) menghasilkan 
bahwa ketidakpastian lingkungan berpengaruh secara positif dan signifikan pada senjangan anggaran. Berdasarkan uraian tersebut dirumuskan hipotesis seperti berikut:

$\mathrm{H}_{3}$ : Ketidakpastian Lingkungan perpengaruh positif pada senjangan anggaran.

Pengaruh budaya organisasi dapat juga mempengaruhi terjadinya senjangan anggaran. Konsep dari budaya itu sendiri menurut Richard (2006: 125) adalah membantu para manajer dalam melakukan pemahaman aspek yang kompleks dari kehidupan suatu organisasi. Budaya merupakan pola nilai dan asumsi tentang sesuatu yang harus dilaksanakan dalam kehidupan berorganisasi. Suatu budaya organisasi telah ada dan diciptakan serta dikembangkan oleh individu yang sudah ada sebelumnya dan akan terus diturunkan kepada setiap anggota individu yang baru agar nilai-nilai ataupun norma-norma yang ada dalam organisasi tidak hilang serta dapat membedakan suatu organisasi dengan organisasi yang lainnya.

Menurut teori goal-setting, budaya organisasi mempunyai pengaruh terhadap prilaku, cara kerja dan motivasi para direktur rumah sakit dan pegawai yang menyusun anggaran untuk mencapai kinerja organisasi yang diatur oleh ide dan niatnya sehingga mempengaruhi tindakan dan konsekuensi kinerjanya. Organisasi dengan budaya yang kuat akan berupaya mengimplementasikan anggaran sesuai dengan apa adanya tanpa tujuan lain. Direktur rumah sakit tidak akan melakukan suatu hal yang dapat dikatakan menyimpang yang dapat merugikan organisasi tempat bekerja.

Penelitian Ramadina (2013), dan Nugroho (2013) didapatkan kesimpulan bahwa budaya organisasi berpengaruh negatif pada senjangan anggaran, yang 
artinya budaya memberikan dampak positif bagi perkembangan organisasi seperti loyalitas anggota, gaya kepemimpinan yang baik dan sebagainya. Budaya yang tertanam kuat dalam diri para anggota organisasi akan menurangi kecenderungan yang mengarah pada terjadinya senjangan anggaran. Berdasarkan uraian tersebut dirumuskan hipotesis seperti berikut:

$\mathrm{H}_{4}$ : Budaya organisasi berpengaruh negatif pada senjangan anggaran.

Faktor lain yang dapat mempengaruhi partisipasi dalam proses penyusunan anggaran sebuah organisasi atau perusahaan adalah komitmen organisasi. Komitmen organisasi merupakan suatu sikap loyalitas karyawan terhadap organisasi melalui penerimaan sasaran-sasaran, nilai-nilai organisasi, kesediaan atau kemauan untuk berusaha menjadi bagian dari organisasi serta keinginan untuk bertahan didalam organisasi. Komitmen organisasi dapat berpengaruh terhadap proses penyusunan anggaran karena didalam proses penyusunan anggaran mengandung komitmen manajemen untuk menyusun dan mencapai target anggaran yang telah ditentukan (Irfan dkk, 2016).

Menurut teori goal-setting, pegawai yang didukung dengan komitmen yang tinggi terhdap organisasi (instansi) pemerintah daerah maka akan lebih mementingkan kepentingan organisasi dari pada kepentingan pribadi. Hal ini akan mendorong pegawai untuk mencapai target anggaran sesuai dengan sasaran yang ingin dicapai oleh organisasi sehingga akan berimplikasi pada pencapaian ketetapan anggaran pendapatan dan belanja daerah (Locke, 1968). Komitmen organisasi merupakan keyakinan dan dukungan yang kuat terhadap nilai dan sasaran (goal) yang ingin dicapai organisasi. 
Penerapan sasaran (goal) yang telah ditetapkan sebelumnya dengan dukungan oleh komitmen organisasi yang tinggi, sehingga setiap pegawai akan lebih mementingkan kepentingan organisasi dari pada kepentingan pribadi atau kelompok dan berusaha keras untuk mencapai sasaran yang telah ditetapkan sebelumnya sehingga berimplikasi pada pencapaian ketetapan anggaran. Pernyataan tersebut didukung oleh penelitian yang dilakukan oleh Agusti (2013), Dewi dan Gerianta (2014), Mukaromah (2015) menunjukan bahwa komitmen organisasi berpengaruh negatif. Berdasarkan uraian tersebut dirumuskan hipotesis seperti berikut:

H5 : Komitmen organisasi berpengaruh negatif pada senjangan anggaran.

\section{METODE PENELITIAN}

Penelitian ini dilakukan dengan menggunakan pendekatan kuantitatif dengan metode penelitian asiosiatif yang bertujuan untuk mengetahui bahwa penyimpangan prilaku dalam partisipasi anggaran dapat menyebabkan terjadinya senjangan anggaran.

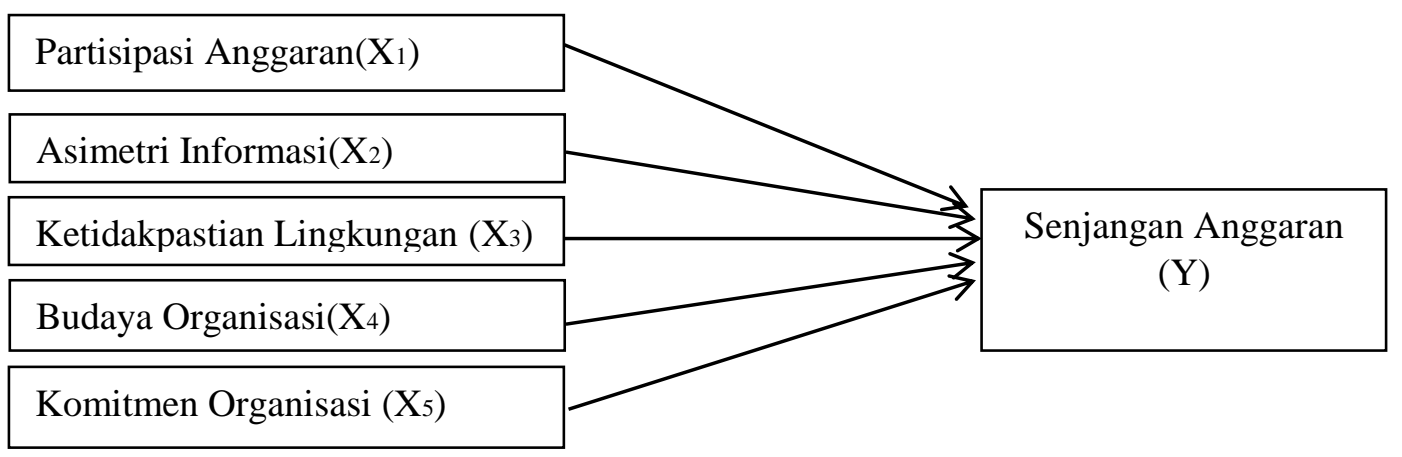

Gambar 1. Desain Penelitian 
Lokasi dalam penelitian ini dilakukan pada Rumah Sakit Umum Daerah Negara. Penentuan lokasi penelitian ini dilakukan dengan alasan bahwa diketahui adanya dugaan terjadinya senjangan anggaran dilihat dari laporan realisasi pendapatan yang tidak diserap secara menyeluruh dan belanja pada tahun 2012 sampai 2016 yang selalu menunjukan realisasi belanja yang lebih tinggi. Sedangkan objek penelitiannya adalah senjangan anggaran di RSUD Negara.

Variabel dependen dalam penelitian ini adalah senjangan anggaran. Senjangan anggaran adalah perbedaan antara jumlah anggaran yang dilaporkan oleh pegawai penyusun anggaran dengan jumlah anggaran yang sesuai dengan estimasi yang sesungguhnya. Variabel senjangan anggaran diukur menggunakan 5 (lima) pernyataan yang diadopsi dari penelitian Carreras (2014) dengan menggunakan skala likert 1-4, yaitu 1 berarti Sangat Tidak Setuju (STS) yang menunjukkan senjangan anggaran yang sangat rendah sampai skala 4 yang artinya Sangat Setuju (SS) yang menunjukkan senjangan anggaran yang sangat tinggi.

Variabel bebas dalam penelitian ini adalah partisipasi, asimetri informasi, ketidakpastian lingkungan, budaya organisasi, dan komitmen organisasi. Variabel partisipasi anggaran diukur dengan 5 (lima) pertanyaan yang diadopsi dari penelitian Douthit (2016). Variabel asimetri informasi diukur dengan 5 (lima) pertanyaan yang diadopsi dari penelitian Eisenhardt (2009). Variabel ketidakpastian lingkungan diukur dengan 5 (lima) pertanyaan yang diadopsi dari penelitian Tambunan (2014). Variabel budaya organisasi diukur dengan 5 (lima) pertanyaan yang diadopsi dari penelitian Dewi (2014). Variabel komitmen 
organisasi diukur dengan 5 (lima) pertanyaan yang diadopsi dari penelitian Meyerd (2013).

Pengukuran masing-masing variabel dilakukan dengan menggunakan kuisioner skala likert dengan skala yang digunakan yaitu skala 4 poin, di mana poin 1 adalah Sangat Tidak Setuju (STS), poin 2 adalah Tidak Setuju (TS), poin 3 adalah Setuju (S), dan poin 4 adalah Sangat Setuju (SS). Alasan menggunakan modifikasi skala likert dengan rentang 1 sampai 4 dalam penelitian ini adalah untuk menghindari adanya tendensi efek kencenderungan responden memilih jawaban ditengah atau jawaban ragu-ragu yang dapat mempengaruhi keandalan data yang dihasilkan (Efferin, dkk, 2008: 109). Dengan menggunakan skala Likert 1-4 maka responden diharapkan untuk secara tegas menyampaikan pendapatnya, apakah setuju atau tidak setuju atas suatu pernyataan atau pertanyaan dalam kuesioner.

Jenis data yang digunakan dalam penelitian ini adalah data kuantitatif berupa jawaban dari responden atas pertanyaan yang terdapat dalam kuesioner yang telah disebar oleh peneliti mengenai senjangan anggaran, partisipasi pengganggaran, asimetri informasi, ketidakpastian lingkungan, budaya organisasi, dan komitmen organisasi yang telah diangkakan dengan menggunakan skala likert. Dan data kualitatif dalam penelitian ini adalah Rumah Sakit Umum Negara.

Sumber data yang digunakan dalam penelitian ini adalah data primer berupa jawaban responden terhadap kuesioner yang telah diajukan kepada responden tersebut. Sedangkan data sekunder dalam penelitian ini berupa sejarah organisasi, dan visi dan misi, struktur organisasi, job description, landasan teori yang 
Anak Agung Gde Wimba Wardhana dan Gayatri. Pengaruh...

diperoleh dari Jurnal Riset Akuntansi, skripsi, tesis serta buku-buku/literatur yang mendukung.

Populasi dalam penelitian ini adalah seluruh pegawai yang berwenang disetiap bidangnya, dalam menyusun anggaran di Rumah Sakit Umum Negara seperti yang tertulis dalam Perda Kabupaten Jembrana No 10 Tahun 2016 (www.jembrana.go.id.). Penelitian ini menggunakan metode sampel jenuh dalam penentuan sampel. Dalam penelitian ini sampel yang akan diambil adalah pegawai yang menduduki jabatan/bagian-bagian bidang tertentu yang ikut dalam menyusun anggaran minimal 2 tahun dengan alasan telah memiliki pengalaman kerja yang lebih mumpuni terhadap kualitas dibidangnya serta turut berkontribusi dalam penyusunan anggaran (Widyaningtyas, 2017).

Metode pengumpulan data yang digunakan dalam penelitian ini adalah metode survei dengan teknik kuesioner, yaitu teknik pengumpulan data yang dilakukan dengan cara memberi seperangkat pertanyaan tertulis kepada responden untuk dijawab (Sugiyono, 2014:199). Kuesioner akan didistribusikan secara langsung ke Rumah Sakit Umum Daerah Negara.

Teknik analisis data yang digunakan dalam penelitian ini adalah regresi linier berganda. Teknik analisis ini digunakan untuk mengetahui pengaruh partisipasi anggaran, asimetri informasi, ketidakpastian lingkungan, budaya organisasi, komitmen oraganisasi, dan senjangan anggaran di Rumah Sakit Umum Daerah Negara.

Rumusan persamaan matematis:

$Y=\alpha+\beta_{1} X_{1}+\beta_{2} X_{2}+\beta_{3} X_{3}+\beta_{4} X_{4}+\beta_{5} X_{5}+e$ 


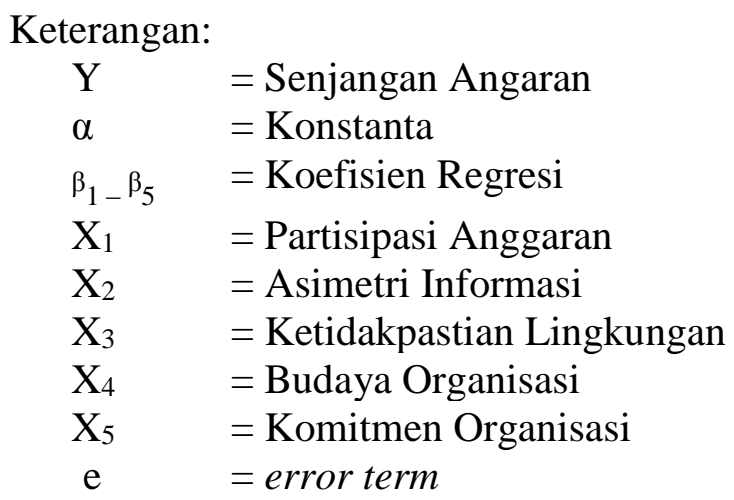

\section{HASIL DAN PEMBAHASAN}

Penelitian ini menggunakan kuesioner sebagai instrumen untuk mengumpulkan data penelitian, berupa pendapat para responden atas serangkaian pernyataan atau pertanyaan yang terdapat di dalam kuesioner. Berdasarkan Tabel 1 dapat dilihat bahwa jumlah kuesioner yang disebar pada penelitian ini sebanyak 40 eksemplar. Dari semua kuesioner yang dikirim maka dapat dirinci seperti tersebut pada Tabel 1 di bawah ini.

Tabel 1.

\section{Perincian Pengembalian dan Penggunaan Kuesioner}

\begin{tabular}{lc}
\hline \multicolumn{1}{c}{ Uraian } & Jumlah Kuesioner \\
\hline Total Kuesioner yang disebar & 40 \\
Kuesioner tidak kembali & 0 \\
Kuesioner yang dikembalikan & 40 \\
Kuesioner yang gugur & 0 \\
Kuesioner yang digunakan & 40 \\
Tingkat Pengembalian (response rate) $=40 / 40 \times 100 \%$ & $100 \%$ \\
Tingkat penggunaan (usable respon rate $)=40 / 40 \times 100 \%$ & $100 \%$
\end{tabular}

Sumber: Data diolah, 2017

Penelitian ini telah menyebarkan kuesioner sebanyak 40 kuesioner dengan tingkat pengembalian responden sebesar 100 persen, dan tingkat penggunaan sebesar 100 persen karena telah diisi dengan lengkap dan memenuhi kriteria. 
Responden dalam penelitian ini adalah 40 orang pegawai pada RSU Negara. Berdasarkan jenis kelamin dari para responden, dijabarkan sebagai berikut.

Tabel 2.

Responden Berdasarkan Jenis Kelamin

\begin{tabular}{ccc}
\hline Jenis Kelamin & Jumlah (orang) & Persentase (\%) \\
\hline Laki-laki & 25 & $62,5 \%$ \\
Perempuan & 15 & $37,5 \%$ \\
Total & 40 & $100 \%$ \\
\hline
\end{tabular}

Sumber: Data diolah, 2017

Berdasarkan Tabel di atas dapat diketahui bahwa dari penelitian terhadap 40 responden menunjukkan bahwa penggolongan berdasarkan jenis kelamin yang paling banyak adalah laki-laki yaitu sebanyak 25 orang atau $62,5 \%$ sedangkan perempuan sebesar 15 orang atau 37,5\% dari total responden.

Tabel 3.

Responden Berdasarkan Usia

\begin{tabular}{ccc}
\hline Umur & Jumlah (orang) & Persentase (\%) \\
\hline $18-30$ tahun & 15 & $37,5 \%$ \\
31 tahun keatas & 25 & $62,5 \%$ \\
Total & 40 & $100 \%$ \\
\hline Sumber: Data diolah 2017 & &
\end{tabular}
Sumber: Data diolah, 2017

Berdasarkan Tabel di atas dapat diketahui bahwa dari penelitian terhadap 40 responden menunjukkan bahwa penggolongan berdasarkan usia yang paling banyak adalah usia 31 tahun keatas sebesar 25 orang atau $62,5 \%$ dari total responden sedangkan usia 18 - 30 tahun yaitu sebanyak 15 orang atau $37,5 \%$ dari total responden. 
Tabel 4.

Responden Berdasarkan Masa Bekerja

\begin{tabular}{ccc}
\hline Masa Bekerja & Jumlah (orang) & Persentase (\%) \\
\hline 2 tahun & 4 & $10 \%$ \\
$3-4$ tahun & 11 & $27,5 \%$ \\
4 tahun keatas & 25 & $62,5 \%$ \\
\hline Total & 40 & $100 \%$
\end{tabular}

Sumber: Data diolah, 2017

Berdasarkan Tabel di atas dapat diketahui bahwa dari penelitian terhadap 40 responden menunjukkan bahwa penggolongan berdasarkan masa bekerja yang paling banyak adalah 4 tahun keatas tahun yaitu sebanyak 25 orang atau $62,5 \%$ dari total responden, sedangkan $3-4$ tahun sebesar 11 orang atau $27,5 \%$ dari total responden dan 2 tahun sebanyak 4 orang atau 14\% dari total responden.

Tabel 5.

Responden Berdasarkan Tingkat Pendidikan

\begin{tabular}{ccc}
\hline Tingkat Pendidikan & Jumlah (orang) & Persentase (\%) \\
\hline D3 & 8 & $20 \%$ \\
S1 & 30 & $75 \%$ \\
S2 & 2 & $5 \%$ \\
\hline Total & 40 & $100 \%$ \\
\hline
\end{tabular}

Sumber: Data diolah, 2017

Berdasarkan Tabel di atas dapat diketahui bahwa dari penelitian terhadap 40 responden menunjukkan bahwa penggolongan berdasarkan tingkat pendidikan yang paling banyak adalah S1 yaitu sebanyak 30 orang atau $75 \%$ dari total responden, sedangkan Diploma sebesar 8 orang atau 20\% dari total responden dan S2 sebanyak 2 orang atau 5\% dari total responden.

Analisis statistik deskriptif dipergunakan untuk menggambarkan suatu data pada variabel penelitian yang dilihat berdasarkan nilai rata-rata (mean), standar 
deviasi, nilai maximum, dan nilai minimum. Berikut merupakan statistik deskriptif dari penelitian ini.

Tabel 6.

Hasil Analisis Statistik Deskriptif

\begin{tabular}{cccccc}
\hline Variabel & N & Minimum & Maximum & Mean & Std. Deviation \\
\hline X1 & 40 & 15.00 & 20.00 & 18.1250 & 1.63593 \\
X2 & 40 & 14.00 & 20.00 & 17.9000 & 1.67638 \\
X3 & 40 & 14.00 & 20.00 & 18.4250 & 1.39390 \\
X4 & 40 & 15.00 & 20.00 & 18.1750 & 1.29867 \\
X5 & 40 & 14.00 & 20.00 & 17.6500 & 1.56156 \\
Y & 40 & 14.00 & 20.00 & 17.2250 & 1.49336 \\
\hline
\end{tabular}

Sumber: Data diolah, 2017

Pengujian validitas dilakukan dengan menghitung nilai pearson correlation. Menurut Sugiyono (2014:363), suatu instrumen dikatakan valid apabila nilai r pearson correlation terhadap skor total di atas 0,304 .

Berdasarkan Tabel 7. menunjukkan bahwa seluruh indikator pernyataan dalam variabel Partisipasi anggaran (X1), Asimetri informasi (X2), Ketidakpastian lingkungan (X3), Budaya Organisasi (X4), Komitmen Organisasi (X5) dan Senjangan anggaran (Y) memiliki pearson correlation yang lebih besar dari r-tabel untuk 40 responden yaitu 0,304 sehingga seluruh indikator tersebut telah memenuhi syarat validitas data. 
Tabel 7.

Hasil Uji Validitas

\begin{tabular}{|c|c|c|c|c|}
\hline No. & Variabel & $\begin{array}{c}\text { Kode } \\
\text { Instrumen }\end{array}$ & $\begin{array}{c}\text { Nilai Pearson } \\
\text { Correlation }\end{array}$ & Keterangan \\
\hline \multirow[t]{5}{*}{1} & $\mathrm{X} 1$ & $\mathrm{X} 1.1$ & 0.446 & Valid \\
\hline & & $\mathrm{X} 1.2$ & 0,672 & Valid \\
\hline & & $\mathrm{X} 1.3$ & 0,827 & Valid \\
\hline & & $\mathrm{X} 1.4$ & 0,723 & Valid \\
\hline & & X1.5 & 0,727 & Valid \\
\hline \multirow[t]{5}{*}{2} & $\mathrm{X} 2$ & $\mathrm{X} 2.1$ & 0,621 & Valid \\
\hline & & $\mathrm{X} 2.2$ & 0,765 & Valid \\
\hline & & $\mathrm{X} 2.3$ & 0,705 & Valid \\
\hline & & $\mathrm{X} 2.4$ & 0,639 & Valid \\
\hline & & $\mathrm{X} 2.5$ & 0,705 & Valid \\
\hline \multirow[t]{5}{*}{3} & X3 & $\mathrm{X} 3.1$ & 0,678 & Valid \\
\hline & & X3.2 & 0,515 & Valid \\
\hline & & X3.3 & 0,699 & Valid \\
\hline & & X3.4 & 0,776 & Valid \\
\hline & & $\mathrm{X} 3.5$ & 0,811 & Valid \\
\hline \multirow[t]{5}{*}{4} & $\mathrm{X} 4$ & $\mathrm{X} 4.1$ & 0,829 & Valid \\
\hline & & $\mathrm{X} 4.2$ & 0,655 & Valid \\
\hline & & $\mathrm{X} 4.3$ & 0,479 & Valid \\
\hline & & $\mathrm{X} 4.4$ & 0,557 & Valid \\
\hline & & $\mathrm{X} 4.5$ & 0,813 & Valid \\
\hline \multirow[t]{5}{*}{5} & $\mathrm{X} 5$ & X5.1 & 0,715 & Valid \\
\hline & & $\mathrm{X} 5.2$ & 0,771 & Valid \\
\hline & & X5.3 & 0,774 & Valid \\
\hline & & X5.4 & 0,741 & Valid \\
\hline & & $\mathrm{X} 5.5$ & 0,459 & Valid \\
\hline \multirow{5}{*}{6} & $\mathrm{Y}$ & Y.1 & 0,751 & Valid \\
\hline & & Y.2 & 0,571 & Valid \\
\hline & & Y.3 & 0,497 & Valid \\
\hline & & Y.4 & 0,770 & Valid \\
\hline & & Y.5 & 0,797 & Valid \\
\hline
\end{tabular}

Sumber: Data diolah, 2017

Pengujian reliabilitas menunjukkan sejauh mana suatu alat pengukur dapat dipercaya atau dapat diandalkan. Uji ini dilakukan terhadap instrumen dengan Cronbach's Alpha, apabila lebih besar dari 0,70 maka instrumen yang digunakan reliabel. Tabel berikut menyajikan hasil uji reliabilitas instrumen penelitian. 
Tabel 8.

\section{Hasil Uji Reliabilitas}

\begin{tabular}{cccc}
\hline No & Variabel & Cronbach's Alpha & Keterangan \\
\hline 1 & $\mathrm{X} 1$ & 0,707 & Reliabel \\
2 & $\mathrm{X} 2$ & 0,721 & Reliabel \\
3 & $\mathrm{X} 3$ & 0,715 & Reliabel \\
4 & $\mathrm{X} 4$ & 0,706 & Reliabel \\
5 & $\mathrm{X} 5$ & 0,736 & Reliabel \\
6 & $\mathrm{Y}$ & 0,710 & Reliabel \\
\hline
\end{tabular}

Sumber: Data diolah, 2017

Berdasarkan Tabel diatas menunjukkan bahwa seluruh indikator pernyataan dalam variabel Partisipasi anggaran (X1), Asimetri informasi (X2), Ketidakpastian lingkungan (X3), Budaya Organisasi (X4), Komitmen Organisasi (X5) dan Senjangan anggaran (Y) memiliki nilai Cronbach's Alpha lebih besar dari 0,70 sehingga pernyataan pada kuesioner tersebut reliabel.

Model regresi dikatakan model yang baik apabila dalam model tersebut bebas dari asumsi klasik. Suatu model regresi linear berganda secara teoritis akan menghasilkan nilai parameter penduga yang tepat bila memenuhi persyaratan uji normalitas, multikolinearitas, dan heteroskedastisitas.

Uji normalitas bertujuan untuk mengetahui apakah dalam residual dari model regresi yang dibuat berdistribusi normal atau tidak dengan menggunakan uji Kolmogorov Smirnov. Apabila koefisien Asymp. Sig. (2-tailed) lebih besar dari 0,05 maka data tersebut dikatakan berdistribusi normal. Hasil uji normalitas dapat dilihat pada tabel berikut. 
Tabel 9.

Hasil Uji Normalitas

\begin{tabular}{lc}
\hline \multicolumn{2}{c}{ One-Sample Kolmogorov-Smirnov Test } \\
\hline Test Statistic & 0,132 \\
Asymp. Sig. (2-tailed) & 0,078 \\
\hline Sumber: Data diolah, 2017 &
\end{tabular}

Berdasarkan tabel diatas dapat dilihat bahwa nilai Asymp. Sig. (2-tailed) 0,078 > 0,05. Hasil tersebut mengindikasikan bahwa model persamaan regresi tersebut berdistribusi normal.

Uji heterokedastisitas bertujuan untuk mengetahui apakah dalam model regresi terjadi ketidaksamaan varians dari residual satu pengamatan ke pengamatan yang lain dan pengujian ini dilakukan dengan uji Glejser. Jika nilai signifikansinya di atas 0.05 maka tidak mengandung gejala heteroskedastisitas.

Tabel 10.

Hasil Uji Heterokedasitas

\begin{tabular}{clc}
\hline No & \multicolumn{1}{c}{ Variabel } & Signifikansi \\
\hline 1 & Partisipasi anggaran (X1) & 0,626 \\
2 & Asimetri informasi (X2) & 0,639 \\
3 & Ketidakpastian lingkungan (X3) & 0,178 \\
4 & Budaya Organisasi (X4) & 0,642 \\
5 & Komitmen Organisasi (X5) & 0,817 \\
\hline Sumber:
\end{tabular}

Sumber: Data diolah, 2017

Berdasarkan Tabel diatas dapat dilihat bahwa nilai signifikansi dari variabel Partisipasi anggaran (X1), Asimetri informasi (X2), Ketidakpastian lingkungan (X3), Budaya Organisasi (X4) dan Komitmen Organisasi (X5) lebih besar dari 0,05 yang berarti tidak terdapat pengaruh antara variabel bebas terhadap absolute residual. Dengan demikian, model yang dibuat tidak mengandung gejala heteroskedastisitas. 
Uji multikoleniaritas bertujuan untuk menguji apakah pada model regresi ditemukan adanya korelasi antar variabel bebas. Adanya multikolinearitas dapat dilihat dari nilai tolerance atau variance inflation factor (VIF). Jika nilai tolerance lebih dari $10 \%$ atau VIF kurang dari 10, maka dikatakan tidak ada multikolinearitas.

Tabel 11.

Hasil Uji Multikoleniaritas

\begin{tabular}{clcc}
\hline No & \multicolumn{1}{c}{ Variabel } & Tolerance & VIF \\
\hline 1 & Partisipasi anggaran (X1) & 0,874 & 1,145 \\
2 & Asimetri informasi (X2) & 0,590 & 1,694 \\
3 & Ketidakpastian lingkungan (X3) & 0,736 & 1,359 \\
4 & Budaya Organisasi (X4) & 0,811 & 1,233 \\
5 & Komitmen Organisasi (X5) & 0,561 & 1,782 \\
\hline
\end{tabular}

Sumber: Data diolah, 2017

Berdasarkan Tabel diatas dapat dilihat bahwa nilai tolerance dan VIF dari variabel Partisipasi anggaran (X1), Asimetri informasi (X2), Ketidakpastian lingkungan (X3), Budaya Organisasi (X4) dan Komitmen Organisasi (X5) menunjukkan bahwa nilai tolerance untuk setiap variabel lebih besar dari $10 \%$ dan nilai VIF lebih kecil dari 10 yang berarti model bebas dari multikolinearitas. Model analisis regresi linear berganda digunakan untuk menentukan apakah hipotesis yang dibuat akan diterima atau ditolak.

Tabel 12.

Hasil Analisis Linear Berganda

\begin{tabular}{cccc}
\hline Variabel & $\begin{array}{c}\text { Unstandardized } \\
\text { coefficients }\end{array}$ & Nilai t & Nilai Signifikan \\
\hline Konstanta & 12,752 & 3,497 & 0,001 \\
X1 & 0,359 & 2,997 & 0,005 \\
X2 & 0,301 & 2,114 & 0,042 \\
X3 & 0,447 & 2,917 & 0,06 \\
X4 & $-0,485$ & $-3,099$ & 0,004 \\
X5 & $-0,386$ & $-2,468$ & 0,019 \\
\hline \multicolumn{4}{c}{ Adjusted $\mathrm{R}^{2}=0,414$} \\
Sumber: Data diolah, 2017
\end{tabular}


Berdasarkan Tabel 12. diatas diperoleh persamaan sebagai berikut:

$Y=a+B_{1} \cdot X_{1}+B_{2} \cdot X_{2}+B_{3} \cdot X_{3}+B_{4} \cdot X_{4}+B_{5} \cdot X_{5}$

$\left.\left.Y=12,752+\left(0,359 X_{1}\right)+\left(0,301 X_{2}\right)+\left(0,447 X_{3}\right)\right)-\left(0,485 X_{4}\right)\right)-\left(0,386 X_{5}\right)$

Hasil analisis model pada Tabel 12. menunjukkan bahwa nilai Adjusted $\mathrm{R}^{2}$ sebesar 0,414. Hal ini berarti 41,4 persen variabel senjangan anggaran mampu dijelaskan oleh variabel partisipasi anggaran, asimetri informasi, ketidakpastian lingkungan, budaya organisasi, dan komitmen organisasi sedangkan sisanya sebesar 58,6 persen dijelaskan oleh faktor-faktor lain yang tidak dijelaskan di dalam model.

Uji F digunakan untuk menguji apakah variabel bebas memiliki pengaruh terhadap variabel terikat secara simultan. Berdasarkan hasil pengolahan data dengan program Statistical Package for the Social Science (SPSS) versi 24 ditemukan hasil pada model penelitian dengan nilai signifikansi $\mathrm{F}=0,000<$ alpha $=0,05$. Hal ini berarti model penelitian yang digunakan pada penelitian ini adalah layak (fit).

Uji t digunakan untuk menguji hipotesis yang menyatakan bahwa variabel bebas yang digunakan dalam penelitian ini memiliki pengaruh terhadap variabel terikat. Hasil pengujian masing-masing sebagai berikut. Hasil uji hipotesis pertama yang disajikan pada Tabel 12. menunjukkan bahwa nilai koefisien beta (b1) adalah 0,359 dengan angka probabilitas dan signifikansi sebesar 0,005 0,05 maka $\mathrm{H}_{1}$ diterima, berarti semakin tinggi tingkat partisipasi dalam penyusunan anggaran, maka dapat meningkatkan terjadinya senjangan anggaran. Partisipasi bawahan dalam penyusunan anggaran sangatlah penting karena bawahanlah yang 
Anak Agung Gde Wimba Wardhana dan Gayatri. Pengaruh...

lebih mengetahui kondisi langsung dari daerah tanggung jawabnya. Partisipasi dalam proses penyusunan anggaran, menyebabkan kemungkinan timbulnya senjnagan anggaran akan lebih besar karena individu tersebut memiliki kesempatan untuk melakukan manipulasi terhadap anggaran. Hasil penelitian ini didukung oleh penelitian Armaeni (2012), Marfuah (2014), Maharani (2015), dan Yanti (2015), yang menyatakan bahwa partisipasi anggaran berpengaruh positif terhadap senjangan anggaran.

Hasil uji hipotesis kedua yang disajikan pada Tabel 12. menunjukkan bahwa nilai koefisien beta $\left(b_{2}\right)$ adalah 0,301 dengan angka probabilitas dan signifikansi sebesar $0,042<0,05$ maka $\mathrm{H}_{2}$ diterima, berarti semakin tinggi tingkat asimetri informasi dalam penyusunan anggaran, maka dapat meningkatkan terjadinya senjangan anggaran. Asimetri informasi sering kali dimanfaatkan oleh bawahan untuk memenuhi kebutuhan pribadinya, dimana bawahan cenderung memberikan informasi bias kepada atasannya. Hasil penelitian ini didukung oleh penelitian yang dilakukan oleh Armaeni (2012), Rukmana (2013), Arthaswadaya (2015), Putra (2015), Tresnayani (2016) menunjukkan bahwa adanya pengaruh positif dari asimetri informasi pada senjangan anggaran.

Hasil uji hipotesis ketiga yang disajikan pada Tabel 12. menunjukkan bahwa nilai koefisien beta $\left(b_{3}\right)$ adalah 0,447 dengan angka probabilitas dan signifikansi sebesar $0,006<0,05$ maka $\mathrm{H}_{3}$ diterima, berarti semakin tinggi tingkat ketidakpastian lingkungan dalam penyusunan anggaran, maka dapat meningkatkan terjadinya senjangan anggaran. Kemampuan memprediksi keadaan dimasa datang pada kondisi ketidakpastian lingkungan yang rendah terjadi pada 
individu yang terlibat dalam penyusunan anggaran. Govindarajan (1986) menyatakan bahwa dalam dalam kondisi ketidakpastian lingkungan yang rendah, partisipasi bawahan yang tinggi akan mampu meningkatkan senjangan anggaran. Hasil penelitian ini didukung oleh penelitian yang dilakukan oleh Kartika (2010) menghasilkan bahwa ketidakpastian lingkungan berpengaruh secara positif dan signifikan pada senjangan anggaran.

Hasil uji hipotesis keempat yang disajikan pada Tabel 12. menunjukkan bahwa nilai koefisien beta $\left(\mathrm{b}_{4}\right)$ adalah $-0,485$ dengan angka probabilitas dan

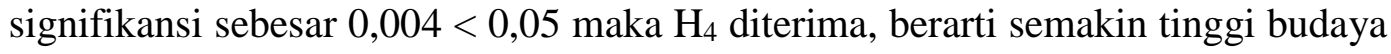
organisasi dalam penyusunan anggaran, maka dapat menurunkan terjadinya senjangan anggaran. Budaya organisasi mempunyai pengaruh terhadap perilaku, cara kerja dan motivasi para manajer dan bawahannya untuk mencapai kinerja organisasi yang diatur oleh ide dan niatnya sehingga mempengaruhi tindakan dan konsekuensi kinerjanya. Organisasi dengan budaya yang kuat akan berupaya mengimplementasikan anggaran sesuai dengan apa adanya tanpa tujuan lain. Hasil penelitian ini didukung oleh penelitian yang dilakukan Ramadina (2013), dan Nugroho (2013) yang menyatakan bahwa budaya organisasi berpengaruh negatif pada senjangan anggaran.

Hasil uji hipotesis kelima yang disajikan pada Tabel 12. menunjukkan bahwa nilai koefisien beta ( $b_{5}$ ) adalah $-0,386$ dengan angka probabilitas dan signifikansi sebesar $0,019<0,05$ maka $\mathrm{H}_{5}$ diterima, berarti semakin tinggi komitmen organisasi dalam penyusunan anggaran, maka dapat menurunkan terjadinya kesenjangan anggaran. Penerapan sasaran yang telah ditetapkan 
sebelumnya dengan dukungan oleh komitmen organisasi yang tinggi, sehingga setiap pegawai akan lebih mementingkan kepentingan organisasi dari pada kepentingan pribadi dan berusaha keras untuk mencapai sasaran yang telah ditetapkan sebelumnya sehingga berimplikasi pada pencapaian ketetapan anggaran. Hasil penelitian ini didukung oleh penelitian yang dilakukan oleh Agusti (2013), Dewi dan Gerianta (2014), Mukaromah (2015) menunjukan bahwa komitmen organisasi berpengaruh negatif.

\section{SIMPULAN}

Berdasarkan pembahasan hasil penelitian di atas, dapat disimpulkan bahwa terdapat pengaruh positif dan signifikan secara parsial antara partisipasi anggaran, asimetri informasi, dan ketidakpastian lingkungan terhadap senjangan anggaran pada RSU Negara. Sedangkan terdapat pengaruh negatif dan signifikan secara parsial antara budaya organisasi dan komitmen organisasi terhadap senjangan anggaran pada RSU Negara. Sementara itu, saran yang dapat diberikan adalah Pihak RSU Negara hendaknya lebih memperhatikan pihak yang ikut dalam partisipasi anggaran, lebih meningkatkan pengawasan secara detail agar arus informasi lebih dikuasi oleh pemimpin, memperhatikan perubahan-perubahan yang terjadi dalam lingkungannya maupun keadaan di masa mendatang, meningkatkan nilai dari budaya organisasi yang dimiliki kepada para pihak yang ikut berpartisipasi dalam menyusun anggaran dan meningkatkan komitmen organisasi kepada para pihak yang ikut berpartisipasi dalam menyusun anggaran agar dapat meminimalisir tingkat senjangan anggaran. 


\section{REFERENSI}

Agusti, R. (2013). Pengaruh Kejelasan Sasaran Anggaran Terhadap Senjangan Anggaran Dengan Dimoderasi Oleh Variabel Komitmen Organisasi dan Informasi Asimetri. Jurnal Ekonomi, 19(4).

Armaeni. (2012). Analisis Pengaruh Partisipasi Anggaran, Informasi Asimetri dan Penekanan Anggaran Terhadap Senjangan Anggaran (Budgetary Slack): Studi Pada SKPD Pemerintah Kabupaten Pinrang). Skripsi. Fakultas Ekonomi dan Bisnis Universitas Hasanuddin.

Arthaswadaya, A. (2015). Pengaruh Asimetri Informasi terhadap Budgetary slack dengan Self Esteem sebagai Variabel Moderasi: Studi Eksperimen dalam Koteks Penganggaran Partisipatif. Skripsi. Fakultas Ekonomi Universitas Negeri Yogyakarta.

Carreras, Maria, D. N. Gil, and S. Gago. (2014). Trust in Superiors and Dysfunctional Behavior. An Experimental Study on Budgetary Slack. Journal of Positive Management, 5(1).

Dewi, N. P., \& N. M. A. Erawati. (2014). Pengaruh Partisipasi Penganggaran, Informasi Asimetris, Penekanan Anggaran, dan Komitmen Organisasi pada Senjangan Anggaran. E-jurnal Akuntansi Universitas Udayana, 9(2): 476-486.

Dewi, N. L. P. S. \& W. Y. Gerianta. (2014). Analisis Pengaruh Anggaran Partisipatif pada Budgetary Slack dengan Empat Variabel Moderasi (Studi Kasus pada SKPD Kabupaten Badung, Bali). E-Jurnal Ekonomi dan Bisnis Universitas Udayana, 3(1): 1-19.

Douthit, J. (2016). The Effect on Endogenous Contract Selection on Budgetary Slack: An Experimental Examination of Trust, Distrust, and Trustworthy. Jurnal of Management Accounting Research, 5.

Dunk, A. S. (1993). The Effect of Budget Emhpasis and Information Asymetry on Relation Between Budgetary Participation and Slack. The Accounting Review, 68(2): 400-410.

Eisenhardt, K. M. (1989). "Agency Theory: An Assessment and Review". Academy of Management Review, 14(1): 57-74.

Faria, J. A. dan S. M. G. D. Silva. (2013). The Effects on Information Asymetry on Budget Slack: A Experimental Research. Academic Journal, 7(13): 1086-1099. 
Govindarajan, V. (1986). Impact of Participation in The Budgetary Process on Managerial Attitudes and Performance: Universalitic and Contingency Perspective.

Harvey, Ellen. (2015). The Effect of employee Ethical Ideology on Organization Budget Slack: An Empirical Examination and Pratical Discusion. Journal of business and economic research, 83-87.

Irfan, M., S. Budi., E. Lukman. (2016). Pengaruh Partisipasi Anggaran terhadap Senjangan Anggaran dengan Asimetri Informasi, Penekanan Anggaran dan Komitmen Organisasional sebagai Variabel Pemoderasi. Jurnal Akuntansi dan Investasi, 17(2): 158-175.

Jensen, M. C. \& W. H Meckling. (1976). Theory of The Firm : Managerial Behavior, Agency Cost and Ownership Structure. Journal of Financial Economics, 3: 305-360.

Kartika, A. (2010). Pengaruh Komitmen Organisasi Dan Ketidakpastian Lingkungan dalam Hubungan Antara Partisipasi Anggaran dengan Senjangan Anggaran (Studi Empirik Pada Rumah Sakit Swasta di Kota Semarang). Jurnal Akuntansi, 39-60.

Kridawan, A. \& M. Amir. (2014). Pengaruh Kejelasan Sasaran Anggaran Terhadap Senjangan Anggaran Dengan Asimetri Informasi Sebagai Variabel Moderasi. Accounting Analysis Journal Universitas Negeri Semarang, 3(2): 194-202.

Latham, G. P., \& G. A. Yukl. (1975). A Review of Research on the Applocation of Goal Setting in Organizations. Academy of Management Journal, 18(4): 824-845.

Lavarda, C. \&D. M. Almeida. (2013). Budget Participation and Informational Asymetry: a study in a multinational company. Brazilian Business Review, 10(2): 72-94.

Lestari, N. K. T., \& I. G. A. M. Asri. (2015). Pengaruh Penganggaran Partisipatif Pada Senjangan Anggaran Dimoderasi Ketidakpastian Lingkungan dan Komitmen Organisasi. E-jurnal Akuntansi Universitas Udayana, 10(2): 474-488.

Locke, E. A. (1968). Toward A Theory of Task Motivation and Incentives. American Institutes of Research, 3(15): 7-89. 
Mahadewi, A. A S. S. (2014). Pengaruh Partisipasi Penganggaran pada Senjangan Anggaran dengan Asimetri Informasi dan Komitmen Organisasi sebagai Variabel Pemoderasi. E-Jurnal Akuntansi Universitas Udayana, 8(3): 458473.

Maharani, A. A. S. S. (2015). Pengaruh Partisipasi Penganggaran pada Senjangan Anggaran dengan Asimetri Informasi dan Komitmen Organisasi sebagai Variabel Pemoderasi. E-Jurnal Akuntansi Universitas Udayana, 12(3): 770-785.

Marfuah, A. L. (2014). Pengaruh Partisipasi Anggaran Terhadap Senjangan Anggaran dengan Menggunakan Komitmen Organisasi dan Informasi Asimetri sebagai Variabel Moderasi. Jurnal Ekonomi dan Bisnis Islam, 8(2): 200-218.

Meyerd, J. P., N. J. Allen., C. A. Smith. (1993). Commitment to organizations and occupations: extension of a test of a three-component conceptualization. Journal of Applied Psychology, 78: 538-551.

Milliken, F. J. (1987). Three Types of Perceived Uncertainty About the Evironment: State, Effect, and Response Uncertainty. Academy of Management Review, 12(1): 133-148.

Mirayanti, A. A. A. P. (2012). Pengaruh Interaksi Partisipasi Penganggaran dan Ketidakpastian Yang Dipersepsikan Terhadap Kinerja Pada Organisasi Non-Profit The Nature Conservacy Indonesia Marine Program. Skripsi. Fakultas Ekonomi Universitas Udayana.

Mowday, R., R. Streers., and L. Porter. (1979). The Measurement of Organizational Commitment. Journal of Vacation Behavior, 14: 224-227.

Mukaromah, A., \& S. Dhini. (2015). Pengaruh Partisipasi Anggaran, Asimetri Informasi, Komitmen Organisasi, Ambiguitas Peran Terhadap Budgetary Slack. Accounting Analysis Journal, 4(4).

Nitiari, N. L. N. (2015). Pengaruh Partisipasi Penganggaran, Komitmen Organisasi, dan Ketidakpastian Lingkungan Pada Senjangan Anggaran. E-Jumal Akuntansi Universitas Udayana, 9(3): 829-841.

Novitasari, N. \& D. G. Wirama. (2015). Pengaruh Pengendalian Anggaran pada Senjangan Anggaran dan Orientasi Jangka Pendek Manajer. E-Jurnal Akuntansi Universitas Udayana, 15(3): 2024-2051. 
Nugroho, Y. T. (2013). Pengaruh Kejelasan Sasaran Anggaran, Asimetri Informasi, dan Budaya Organisasi Terhadap Senjangan Anggaran (Studi Empiris Pada SKPD-SKPD di Kabupaten Jember). Skripsi. Fakultas Ekonomi Universitas Jember.

Pello, E. V. (2014). Pengaruh Asimetri Informasi, Locus of Control pada Hubungan antara Penganggaran Partisipatif dengan Senjangan Anggaran. E-Jurnal Akuntansi Universitas Udayana, 6(2): 287-305.

Pratami, A. A., \& S. G. Desy. (2015). Pengaruh Partisipasi Penganggaran terhadap Senjangan Anggaran dengan Penekanan Anggaran dan Ketidakpastian Lingkungan sebagai Pemoderasi. E-Jurnal Akuntansi Universitas Udayana, 5(2): 1565-1594.

Putra, I. N. T., I. M. P. Adiputra., \& N. T. Herawati. (2015). Analisis Pengaruh Partisipasi Anggaran, Informasi Asimetri Dan Penekanan Anggaran Terhadap Senjangan Anggaran (Budgetary slack) (Studi Pada SKPD Pemerintah Kabupaten Buleleng). E-Jurnal Universitas Pendidikan Ganesha, 3(1): 7-8.

Ramadina, W. (2013). Pengaruh Partisipasi Anggaran Terhadap Senjangan Anggaran dengan Gaya Kepemimpinan dan Budaya Organisasi sebagai Variable Moderasi (Studi Empiris pada Satuan Kerja Perangkat Daerah Kota Payakumbuh). Skripsi. Fakultas Ekonomi Universitas Negeri Padang.

Richard, L. D. (2006). Management. Sixth Edition. Singapore Thomson Learning Asia.

Rukmana, P. (2013). Pengaruh Partisipasi Penganggaran dan Asimetri Informasi Terhadap Timbulnya Budgetary Slack (Studi Empiris Pada Pemerintah Kota Padang). Skripsi. Fakultas Ekonomi Universitas Negeri Padang.

Siegel, G., \& H. R. Marconi. (1989). Behavioural Accounting. South Western Publishing Company.

Sugiyono. (2014). Metode Penelitian Bisnis Pendekatan Kuantitatif, Kualitatif dan $R \& D$. Badung: Alfabeta.

Sularso, H. R., \& Istiqomah. (2014). Determinan Perilaku Oportunistik Penyusun Anggaran (Studi pada Kabupaten/Kota di Jawa Tengah). Universitas Mataram.

Tambunan, H., \& Kurniawan. (2014). Pengaruh Partisipasi Penganggaran Terhadap Senjangan Anggaran Dengan Komitmen Organisasi Dan Ketidakpastian Lingkungan Sebagai Variabel Moderating. Skripsi. Fakultas Ekonomi Universitas Atmajaya Yogyakarta. 
Tresnayani, L. G. A., \& Gayatri. (2016). Pengaruh Partisipasi Anggaran, Asimetri Informasi, Kapasitas Individu, Dan Kejelasan Sasaran Anggaran Terhadap Potensi Terjadinya Budgetary Slack. E-jurnal Akuntansi Universitas Udayana, 16(2): 1405-1432.

Yanti, N. W. M. (2016). Asimetri Informasi sebagai Pemoderasi Pengaruh Partisipasi Penganggaran dan Kejelasan Anggran pada Senjangan Anggaran (Studi Empiris pada Satuan Kerja Perangkat Daerah Kabupaten Tabanan). E-Jurnal Akuntansi Universitas Udayana, 15(1): 257-285. 